Finanse, Rynki Finansowe, Ubezpieczenia nr 3/2017 (87), cz. 1

\title{
Jakość audytu wewnętrznego a wartość dodana w jednostkach sektora finansów publicznych
}

\author{
Elżbieta Izabela Szczepankiewicz*
}

\begin{abstract}
Streszczenie: $\mathrm{Cel}$ - Omówienie istoty wartości dodanej, którą przysparza jednostce audyt wewnętrzny, a także wpływu wdrożenia programu oceny i poprawy jakości audytu na zwiększenie wartości dodanej dla komórki audytu wewnętrznego i jednostki jako całości.

Metodologia badania - Analiza krytyczna literatury, standardów i przepisów prawnych, metoda dedukcyjna oraz synteza wniosków z analizy.

Wynik - Przedstawiono wyniki badań ankietowych na temat jakości audytu wewnętrznego w wybranych jednostkach sektora finansów publicznych w województwie wielkopolskim.

Oryginalność/wartość - Przedstawione wyniki badań mogą stanowić asumpt dla teoretyków do dalszych zaawansowanych badań nad zagadnieniami pomiaru i doskonalenia jakości audytu wewnętrznego w jednostkach sektora finansów publicznych.
\end{abstract}

Slowa kluczowe: audyt wewnętrzny, wartość dodana, przysparzanie wartości

\section{Wprowadzenie}

Zagadnienia dotyczące pomiaru jakości audytu wewnętrznego oraz doskonalenie jego funkcjonowania $\mathrm{w}$ jednostkach sektora finansów publicznych (JSFP) były dotychczas bardzo rzadko opisywane w krajowej literaturze naukowej (Bednarek, 2014; Bednarek, 2015; Zaleska, 2015; Nadolna, 2016; Szczepankiewicz, Młodzik, 2016), chociaż temat ten jest niezwykle ważny dla sektora finansów publicznych, gdzie audyt wewnętrzny funkcjonuje już 15 lat. Funkcjonowanie audytu wewnętrznego w JSFP od samego początku, czyli od 2002 roku było i jest ściśle regulowane przepisami prawa (obecnie: Ustawa z dnia 27 sierpnia 2009 r.; Rozporządzenie z dnia 4 września 2015 r.) a także standardami i wieloma wytycznymi Ministra Finansów. Początkowo audyt wewnętrzny w JSFP regulowały krajowe standardy audytu wewnętrznego. Od 2006 roku w JSFP przyjęło do praktyki Międzynarodowe standardy praktyki zawodowej audytu wewnętrznego, ogłoszone przez Instytut Audytorów Wewnętrznych (Institute of Internal Auditors - IIA), zwane dalej Standardami audytu wewnętrznego (Międzynarodowe Standardy..., 2016).

\footnotetext{
* dr Elżbieta Izabela Szczepankiewicz, Uniwersytet Ekonomiczny w Poznaniu, Wydział Zarządzania, Katedra Rachunkowości, e-mail: elzbieta.szczepankiewicz@ue.poznan.pl.
} 
Zgodnie ze Standardami audytu wewnętrznego, podstawowym celem audytu wewnętrznego jest przysparzanie wartości jednostce, w której jest on prowadzony. $Z$ efektywnym funkcjonowaniem audytu wewnętrznego $\mathrm{w}$ jednostce wiąże się potrzeba prowadzenia oceny i doskonalenia jego jakości. W JSFP przewidziano tę potrzebę już w 2003 roku, w pierwszych krajowych standardach audytu wewnętrznego. Minister Finansów ogłosił wówczas pierwsze Wytyczne do samooceny audytu wewnętrznego w jednostkach sektora finansów publicznych (2003), których treść uwzględniała ówczesne krajowe standardy audytu wewnętrznego. Nowe wytyczne w zakresie samooceny audytu wewnętrznego w JSFP ogłoszono w 2007 roku (Wytyczne do samooceny audytu..., 2007). Zmiana wytycznych w tym zakresie była związana z wdrożeniem w 2006 roku do praktyki JSFP Międzynarodowych standardów profesjonalnej praktyki audytu wewnętrznego, ogłoszonych przez IIA. Wytyczne z 2007 roku nadal obowiązują w sektorze JSFP i nie były później zmieniane a jedynie zaktualizowane. Po pięciu latach od tego czasu Ministerstwo Finansów ogłosiło także $W y$ tyczne w zakresie programu zapewnienia i poprawy jakości (2012), których również nie zmieniano w późniejszych latach.

Celem artykułu jest omówienie istoty wartości dodanej, którą przysparza jednostce audyt wewnętrzny, a także wpływu wdrożenia programu oceny i doskonalenia jakości audytu wewnętrznego na zwiększenie wartości dodanej dla komórki audytu i jednostki. W części empirycznej przedstawiono wyniki badań ankietowych w przedmiotowym zakresie, które przeprowadzono wśród kadry kierowniczej w wybranych JSFP w województwie wielkopolskim ${ }^{1}$.

\section{Przysparzanie wartości dodanej przez audyt wewnętrzny w jednostce}

Obecnie obowiązująca definicja pojęcia audyt wewnętrzny według Standardów audytu wewnętrznego stanowi, że jest to działalność niezależna i obiektywna, której celem jest przysporzenie wartości, usprawnienie działalności operacyjnej jednostki i przyczynienie się do poprawy jej działania. Audyt wewnętrzny powinien pomóc jednostce osiągnąc jej cele, dostarczając zapewnienia o skuteczności procesów zachodzących w jednostce, a także świadczyć czynności doradcze (Definicja audytu..., 2016). Pojęcie przysparzanie wartości zostało objaśnione w słowniku Standardów audytu wewnętrznego w następujący sposób: „Komórka audytu przysparza wartości jednostce i jej interesariuszom, kiedy dostarcza obiektywnego zapewnienia $\mathrm{w}$ istotnych kwestiach oraz przyczynia się do skuteczności i wydajności procesów: ładu organizacyjnego, zarządzania ryzykiem i kontroli”. O przysparzaniu wartości mówi także interpretacja IIA do Standardu 2000 - Zarządzanie audytem wewnętrznym. Zgodnie z tą interpretacją audyt wewnętrzny przysparza wartości jednostce jeśli:

\footnotetext{
${ }^{1}$ Artykuł powstał w ramach międzyuczelnianego projektu naukowego nr 51109-XX5 „Teoretyczne i praktyczne aspekty oceny funkcji audytu wewnętrznego w sektorze publicznym” zarejestrowanym w UE w Poznaniu.
} 
- w swoim działaniu bierze pod uwagę strategie, cele i ryzyko,

- obiektywnie zapewnia o badanych kwestiach,

- stara się proponować sposoby wzmocnienia procesów: ładu organizacyjnego, zarządzania ryzykiem i kontroli.

Powyższą interpretację IIA wzmocniono treścią niektórych Standardów audytu wewnętrznego. Przykładowo Standard 2130 - Kontrola zakłada, że audyt wewnętrzny musi wspierać jednostkę (przez ocenę skuteczności i wydajności) w utrzymaniu skutecznych mechanizmów kontrolnych i promować ciągłe ich usprawnianie. Standard wdrożenia 2210. C2 zawierający wytyczne do prowadzenia czynności doradczych również odnosi się do aspektów przysporzenia wartości przez audyt wewnętrzny. Stanowi mianowicie, że cele zadań doradczych muszą być zgodne z wartościami, strategiami i celami organizacji. W słowniku do Standardów audytu wewnętrznego wskazano, że celem usług doradczych, takich jak: konsultacja, doradztwo, facylitacja czy szkolenie, jest również przysporzenie wartości i usprawnienie procesów ładu organizacyjnego, zarządzania ryzykiem i kontroli (Komunikat z 12 grudnia 2016 r.).

Podstawowa wartość dodana przysparzana jest jednostce w wyniku otrzymywania przez kierownictwo niezależnej i obiektywnej oceny od audytu wewnętrznego na temat funkcjonowania badanych obszarów, procesów, systemów, działań czy komórek organizacyjnych. Natomiast dodatkową wartość dodaną do jednostki wnoszą usługi doradcze świadczone przez audyt wewnętrzny. Zatem niezależna, obiektywna ocena i rekomendacje, a także usługi doradcze audytu wewnętrznego, jeśli są przydatne kierownictwu jednostki do doskonalenia obiektów oceny, czyli procesów zarządzania, nadzoru organizacyjnego, kontroli wewnętrznej (zarządczej) i zarządzania ryzykiem, są same w sobie wartością dodaną dla jednostki.

W kontekście powyższych definicji, zdaniem autorki można sformułować tezę, że zarówno szeroki zakres, jak i sam charakter usług zapewniających i doradczych świadczonych przez audyt wewnętrzny, przysparza jednostce wartości dodanej, a im wyższa jakość usług świadczonych przez audytorów dla kierownictwa jednostki, które na tej podstawie może doskonalić funkcjonowanie jednostki, tym wyższa wartość dodana wnoszona przez audyt wewnętrzny do jednostki. Doskonalenie jakości usług audytu wewnętrznego może wspomagać wdrożenie programu zapewnienia i poprawy jego jakości.

\section{Istota i cele programu zapewnienia i poprawy jakości audytu wewnętrznego}

W myśl zapisów Standardów audytu wewnętrznego, kierownik komórki audytu wewnętrznego powinien opracować i realizować program zapewnienia i poprawy jakości, który obejmuje wszystkie aspekty audytu² oraz monitorować w sposób ciągły jego efektywność.

\footnotetext{
${ }^{2}$ Zgodnie ze Standardem 1300 - Program zapewnienia i poprawy jakości (Definicja audytu..., 2016).
} 
Zgodnie z interpretacją IIA do Standardu 1300 celem tego programu jest między innymi ocena wydajności i skuteczności audytu wewnętrznego oraz identyfikacja możliwości poprawy (Definicja audytu..., 2016).

Cele funkcjonowania programu zapewnienia i doskonalenia jakości audytu wewnętrznego w każdej jednostce powinny być skorelowane z rolą i celami jego funkcjonowania. Zatem program zapewnienia i poprawy jakości audytu wewnętrznego powinien również przysparzać wartości dodanej zarówno jednostce, w której audyt jest prowadzony, jak i samej komórce audytu wewnętrznego.

W wyniku wdrożenia programu zapewnienia i poprawy jakości audytu wewnętrznego powinno nastąpić usprawnienie organizacji i jakości usług świadczonych przez komórkę audytu. Program powinien wspomagać kierownika komórki audytu wewnętrznego w uzyskaniu wiarygodnych informacji na temat funkcjonowania tej komórki, jakości pracy audytorów oraz ułatwiać pomiar efektywności, wydajności i skuteczności, a także bieżące identyfikowanie obszarów do usprawnienia audytu wewnętrznego. Wdrożenie programu zapewnienia i poprawy jakości powinno też przyczynić się do poprawy stosunków audytorów z kierownikami i pracownikami komórek audytowanych.

Wysoka jakość usług oraz właściwe relacje audytorów z interesariuszami audytu w jednostce powinny przełożyć się na poprawę funkcjonowania zarówno komórki audytu wewnętrznego, jak i całej jednostki. W ten sposób można sformułować drugą tezę, że wdrożenie programu oceny i poprawy jakości audytu wewnętrznego buduje zaufanie interesariuszy audytu i tworzy dodatkową wartość dodaną. Regularne przeprowadzanie ocen jakości audytu wewnętrznego pomaga kierownictwu jednostek oraz innym interesariuszom audytu w dostrzeżeniu roli audytu, wniesionej wartości i zalet jego przeprowadzania. Otrzymane od audytorów wewnętrznych wyniki oceny obszarów objętych badaniem mogą udowodnić, że audyt wewnętrzny jest przydatny do zarządzania i zbieżny z oczekiwaniami kierownictwa jednostki.

Każdy element programu zapewnienia i poprawy jakości audytu wewnętrznego powinien być zaprojektowany w taki sposób, by wspierał działania audytu zmierzające do przysporzenia wartości i poprawy funkcjonowania jednostki oraz zapewniał zgodność działania audytu z Kartą audytu wewnętrznego, Standardami audytu wewnętrznego, Kodeksem etyki. Program powinien dostarczyć także racjonalnego zapewnienia kierownikowi jednostki, kierownikom komórek audytowanych, komitetowi audytu, opinii publicznej i innym interesariuszom, że audyt wewnętrzny funkcjonuje w sposób efektywny, skuteczny, wydajny i zgodnie z obowiązującymi jednostkę regulacjami. Powinien być postrzegany przez zainteresowane osoby jako przysparzający wartości dodanej i usprawniający funkcjonowanie jednostki we wszystkich aspektach jej działalności. 


\section{Prezentacja wyników badań empirycznych}

Próba badawcza jednostek przyjętych do przeprowadzenia badań pilotażowych przez autorkę obejmowała kadrę kierowniczą oraz dokumentację wewnętrzną z wybranych JSFP w województwie wielkopolskim. Jednostki badane dysponowały własnymi komórkami audytu wewnętrznego. Wyniki przydatne do analizy uzyskano z 96,25\% jednostek objętych badaniem.

Na podstawie przeprowadzonych badań ustalono, że interesariuszami sprawozdań audytu wewnętrznego w badanych JSFP są:

- kierownik jednostki,

- kierownicy komórek audytowanych,

- skarbnik,

- sekretarz,

- radni,

- jednostka nadrzędna,

- inne osoby z tzw. grona opinii publicznej.

W tabeli 1 zaprezentowano wyniki badań z uzyskanych odpowiedzi na pytania dotyczące funkcjonowania audytu wewnętrznego w JSFP. Pytania skierowano w szczególności do kierowników komórek audytowanych w obszarze finansów i rachunkowości oraz administracji jednostki.

\section{Tabela 1}

Odpowiedzi ankietowanych na temat jakości funkcjonowania audytu w wybranych JSFP

\begin{tabular}{lccc}
\hline Pytanie & \multicolumn{3}{c}{ Odpowiedź (\%) } \\
\cline { 2 - 4 } & tak & nie & $\begin{array}{c}\text { trudno } \\
\text { to ocenić }\end{array}$ \\
\hline $\begin{array}{l}\text { Czy Pani/Pana zdaniem audyt wewnętrzny przyczynił się do usprawnienia } \\
\text { działalności jednostki/wniósł wartość dodaną? }\end{array}$ & 69 & 9 & 23 \\
$\begin{array}{l}\text { Czy Pani/Pana zdaniem audyt wewnętrzny w jednostce świadczy usługi o wysokiej } \\
\text { jakości? }\end{array}$ & 58 & 15 & 27 \\
$\begin{array}{l}\text { Czy Pani/Pana zdaniem istnieje potrzeba prowadzenia audytu wewnętrznego } \\
\quad \text { jednostce? }\end{array}$ & 76 & 5 & 19 \\
$\begin{array}{l}\text { Czy Pani/Pana zdaniem system kontroli zarządczej i nadzór organizacyjny jest } \\
\text { na tyle adekwatny, sprawny, efektywny, że nie wymaga prowadzenia audytu } \\
\text { wewnętrznego? }\end{array}$ & 38 & 48 & 14 \\
$\begin{array}{l}\text { Czy Pani/Pana zdaniem, jeśli audyt wewnętrzny nie byłby obowiązkowy w jednostce } \\
\text { to czy kierownictwo z niego by zrezygnowało? }\end{array}$ & 12 & 62 & 26 \\
\hline
\end{tabular}

Źródło: opracowanie własne.

Na podstawie przeprowadzonych badań można stwierdzić, że odpowiedź „tak” na pytania 1-3 oznacza, że usługi audytu wewnętrznego zdaniem ankietowanych są potrzebne i jednoznacznie przysporzyły JSFP wartości dodanej. Ankietowani byli również zobowiązani do uzasadnienia odpowiedzi: „nie” oraz „trudno to ocenić”. Odpowiedź „nie” uzasadniano 
najczęściej stwierdzeniem, że audyt wewnętrzny świadczył usługi na tak niskim poziomie, że kadra kierownicza nie była w stanie wykorzystać jego wyników do polepszenia funkcjonowania komórki audytowanej w badanym obszarze. Odpowiedź „trudno to ocenić” padała natomiast w przypadku, gdy:

a) usługi audytu wewnętrznego, zdaniem ankietowanych, nie stanowiły ważnego aspektu dla prowadzenia działalności JSFP lub komórki audytowanej;

b) prowadzenie audytu wewnętrznego wynikało $\mathrm{z}$ obowiązku wyznaczonego przez określone regulacje (przepisy prawa i regulacje wewnętrzne), ale jego wyniki nie są brane lub były rzadko brane pod uwagę przez kierownictwo;

c) wyniki audytu wewnętrznego nie zawierały istotnych wniosków i/lub znaczących rekomendacji dla badanego obszaru;

d) wyniki audytu wewnętrznego nie wniosły istotnych rekomendacji dla badanego obszaru, ponieważ w badanym obszarze dobrze funkcjonuje system kontroli zarządczej.

Tylko 38\% ankietowanych z badanych JSFP uznaje, że system kontroli zarządczej i nadzór organizacyjny jest na tyle adekwatny, sprawny, efektywny, że nie wymaga prowadzenia audytu wewnętrznego. Aż $48 \%$ ankietowanych uważa, że system kontroli zarządczej i nadzór organizacyjny wymaga oceny okresowej przez audyt wewnętrzny. Tylko $12 \%$ ankietowanych z badanych JSFP uznaje, że można byłoby zrezygnować z audytu wewnętrznego w jednostkach, w których są zatrudnieni, jeśli nie byłby on obowiązkowy. Oznacza to, że ich zdaniem prowadzenie audytu wewnętrznego jest uzasadnione i nie wynika jedynie z formalnego obowiązku nałożonego przepisami prawa.

W 90\% analizowanych JSFP opracowano program zapewnienia i poprawy jakości audytu wewnętrznego. Programy te są wprowadzane w jednostkach na podstawie zarządzenia kierownika jednostki. Do programu zapewnienia i poprawy jakości audytu wewnętrznego w tych jednostkach zostały włączone wszystkie podstawowe aspekty funkcjonowania audytu wynikające ze Standardów audytu wewnętrznego i innych regulacji w tym zakresie, w tym:

- opracowywanie planu audytu wewnętrznego na rok następny,

- sporządzanie sprawozdania z wykonania planu audytu wewnętrznego za rok poprzedni,

- przegląd akt bieżących prowadzony we własnym zakresie, np. pod kątem sprawdzenia kompletności dokumentacji,

- prowadzenie list sprawdzających, które potwierdzały, że czynności audytora przebiegały w sposób zgodny ze standardami i przyjętymi procedurami,

- pozyskiwanie informacji zwrotnej (ankiety poaudytowe) od audytowanych, kierownika jednostki i innych zainteresowanych stron, na bieżąco po zakończonym zadaniu,

- przeprowadzanie corocznej samooceny,

- przeprowadzanie okresowej oceny zewnętrznej (co 5 lat lub częściej).

W analizowanych zarządzeniach dotyczących programów zapewnienia i poprawy jakości zawsze widniał zapis wskazujący kierownika komórki audytu wewnętrznego, jako osobę odpowiedzialną za realizację tych programów. W każdej badanej JSFP kierownik 
komórki audytu (lub audytor wewnętrzny w przypadku stanowiska jednoosobowego) jest odpowiedzialny za wdrożenie procesów, których celem jest dostarczenie racjonalnego zapewnienia, że audyt wewnętrzny działa w sposób efektywny i skuteczny zgodnie z:

a) Kartą audytu wewnętrznego, zgodną z Międzynarodowymi standardami praktyki zawodowej audytu wewnętrznego (2016) oraz załącznikiem nr 1 do Komunikatu Ministra Finansów nr 16 (2006);

b) Kodeksem etyki w jednostkach sektora finansów publicznych (załącznik nr 2 do Komunikatu Ministra Finansów nr 16, 2006);

c) Księgą procedur audytu wewnętrznego, stanowiącą metodykę przeprowadzania audytu;

d) odpowiednimi przepisami prawa i regulacjami wewnętrznymi obowiązującymi daną jednostkę.

Programy w badanych JSFP obejmowały szczegółowe zasady dokonywania bieżącego monitoringu działań audytu wewnętrznego, zasady okresowych przeglądów dokonywanych drogą samooceny oraz zasady dokonywania okresowych ocen zewnętrznych.

We wszystkich badanych JSFP, w programach zapewnienia i poprawy jakości, zgodnie ze Standardami audytu wewnętrznego, przyjęto że ocena wewnętrzna obejmuje:

- bieżącą ocenę w formie monitoringu działalności audytu wewnętrznego,

- okresowe przeglądy przeprowadzane drogą samooceny lub przez inną osobę w jednostce $\mathrm{z}$ wystarczającą znajomością praktyki audytu wewnętrznego.

W analizowanych JSFP bieżący monitoring działalności komórki audytu wewnętrznego został włączony do codziennych zasad i czynności audytu jako element stałego i codziennego nadzoru, przeglądu i pomiaru efektywności audytu wewnętrznego. Stanowi on element zarządzania działalnością komórki audytu. Bieżący monitoring wykonuje się w tych jednostkach w ramach zadań i obowiązków kierownika komórki audytu poprzez:

- monitorowanie przestrzegania przepisów prawa, standardów, wytycznych i wewnętrznych procedur regulujących funkcjonowanie audytu wewnętrznego,

- koordynowanie prac związanych z przygotowaniem rocznego planu audytu,

- monitorowanie terminowego i prawidłowego przeprowadzania zadań audytowych, w tym programów zadań audytowych i sprawozdań z przeprowadzonych zadań,

- ocenę harmonogramów i budżetów czasowych,

- ocenę realizacji planu audytu,

- przegląd akt bieżących i stałych audytu,

- przegląd procedur audytu i ich weryfikacja,

- ocenę prac związanych z przygotowaniem rocznego sprawozdania z wykonania planu audytu.

Ponadto, w ramach bieżącej oceny wewnętrznej działalności audytu wewnętrznego po przeprowadzeniu każdego zadania audytowego audytorzy wewnętrzni w badanych JSFP wypełniali listy sprawdzające, zgodnie ze wzorem umieszczonym w załącznikach do programów zapewnienia i poprawy jakości. Dodatkowo w badanych jednostkach kierownicy 
komórek audytowanych (albo osoby przez nich wyznaczone) wypełniały ankiety poaudytowe oceniające usługi audytu wewnętrznego, zgodnie z wzorami umieszczonymi w załącznikach do tych programów.

Przeglądy okresowe dokonywane w procesie samooceny prowadzone były w badanych JSFP w celu oceny zgodności działania audytu wewnętrznego z przepisami prawa oraz regulacjami wewnętrznymi obowiązującymi daną jednostkę. Przeglądy okresowe umożliwiają ocenę skuteczności i efektywności audytu z uwzględnieniem czasu przeznaczonego na wykonanie zadań audytowych przez porównanie z planem audytu. Kwestionariusze samooceny stanowiły załącznik do programów zapewnienia i poprawy jakości. W analizowanych dokumentach wewnętrznych badanych jednostek były one zazwyczaj kopią Wytycznych Ministra Finansów w tym zakresie.

W większości badanych JSFP przeprowadzono co najmniej dwukrotnie oceny zewnętrzne. Oceny te przeprowadzano z częstotliwością wskazaną w Standardach audytu wewnętrznego, czyli nie rzadziej niż raz na 5 lat. $Z$ analizowanych programów zapewnienia i poprawy jakości wynikało, że ocenę zewnętrzną w badanych jednostkach przeprowadzały niezależne osoby spoza jednostek, które miały stosowne kwalifikacje. Ocena zewnętrzna w większości badanych jednostek była realizowana w formie:

- pełnej oceny zewnętrznej, którą przeprowadzała wykwalifikowana i niezależna osoba lub zespół spoza jednostki, np. z jednostki nadrzędnej, albo

- samooceny z niezależnym potwierdzeniem zewnętrznym wykonanym przez wykwalifikowaną i niezależną osobę lub zespół spoza jednostki.

W kilku badanych JSFP przyjęto formę przeglądu partnerskiego przez osoby lub zespoły audytorów, czyli tzw. wolontariat pomiędzy jednostkami (komórkami audytu wewnętrznego) z tej samej grupy jednostek lub z różnych JSFP. Rozwiązanie takie jest zgodne ze Standardami audytu wewnętrznego. Aby jednak zapewnić warunek obiektywizmu i pełnej niezależności zespołu/osoby dokonującej oceny zewnętrznej, przyjęto w jednostkach takie rozwiązanie, że przeglądy partnerskie nie mogły się odbywać wzajemnie pomiędzy dwiema jednostkami. Przeglądy odbywały się co najmniej w trzech lub więcej jednostkach, aby zminimalizować obawy naruszenia niezależności osób oceniających.

Należy podkreślić, że w przypadku wykrycia niezgodności ze Standardami audytu wewnętrznego lub innymi regulacjami, podczas ocen wewnętrznych w programach wskazano obowiązek podjęcia odpowiednich działań w celu osiągnięcia zgodności i dokonania stosownych usprawnień funkcjonowania komórki audytu wewnętrznego. Również w razie istotnych uwag i zaleceń do wyników oceny zewnętrznej, program zapewnienia i poprawy jakości zobowiązywał do sporządzenia pisemnego planu działań naprawczych.

\section{Uwagi końcowe}

Właściwie opracowany, wdrożony i realizowany program zapewnienia i poprawy jakości audytu wewnętrznego stanowi podstawę do przeprowadzania działań usprawniających 
funkcjonowanie komórki audytu w jednostce. Zamieszczone na stronach internetowych IIA oraz Ministerstwa Finansów opracowania dotyczące takich modeli i narzędzi, jak Model IA - $\mathrm{CM}$, benchmarking i inne, stanowią zaawansowane instrumenty usprawniania działalności audytu wewnętrznego. Ich zastosowanie jednak musi zostać poprzedzone odpowiednimi działaniami prowadzonymi już na poziomie planowania programu zapewnienia i poprawy jakości audytu wewnętrznego.

Należy podkreślić, że Standardy audytu wewnętrznego zobowiązują kierownika komórki audytu do nadzorowania programu zapewnienia i poprawy jakości audytu wewnętrznego. Zatem od jego sprawności, skuteczności działań i cech osobowych zależy, czy interesariusze audytu uzyskają usługi audytu wewnętrznego o najwyższej jakości przysparzające jednostce wartości dodanej. Dlatego w programach zapewnienia i poprawy jakości bardzo ważne są zapisy wymagające podjęcia określonych działań naprawczych i usprawniających po zdiagnozowaniu braków i nieprawidłowości w trakcie bieżącego monitorowania, a także po przeprowadzonych ocenach wewnętrznych i zewnętrznych. Wszystkie analizowane jednostki miały taki zapis w programach zapewnienia i poprawy jakości audytu wewnętrznego.

Należy podkreślić, że analizowane JSFP nie posiadały żadnych wskaźników oraz mierników efektywności i skuteczności audytu wewnętrznego, które mogłyby wskazywać jaki poziom wartości dodanej przysparzają jednostce czynności zapewniające i doradcze audytu wewnętrznego. Oznacza to, że istnieje luka w tym zakresie, a przedstawione rezultaty badań pilotażowych potwierdzają konieczność prowadzenia dalszych zaawansowanych badań nad złożonymi zagadnieniami pomiaru i doskonalenia jakości audytu wewnętrznego w JSFP. Pożądane byłoby opracowanie listy prostych wskaźników i mierników (ilościowych i jakościowych), które mogłoby wykorzystywać kierownictwo i audytorzy do doskonalenia jakości audytu wewnętrznego w JSFP.

\section{Literatura}

Bednarek, P. (2014). Samoocena audytu wewnętrznego w Polsce: stan wiedzy i kierunki dalszych badań. Prace Naukowe Uniwersytetu Ekonomicznego we Wrocławiu, 343, 31-41.

Bednarek, P. (2015). Samoocena $w$ audycie wewnętrznym jednostek sektora finansów publicznych. Wrocław: Wydawnictwo Uniwersytetu Ekonomicznego we Wrocławiu.

Definicja audytu wewnętrznego, Kodeks etyki oraz Międzynarodowe Standardy Praktyki Zawodowej Audytu Wewnętrznego (2016). The Institute of Internal Auditors, USA, Tłum. IIA - Polska, Warszawa. Pobrane z: www. iia.org.pl (16.03.2017).

Komunikat Ministra Rozwoju i Finansów z 12 grudnia 2016 r. w sprawie standardów audytu wewnętrznego dla jednostek sektora finansów publicznych (Dz. Urz. Min. Rozw. i Fin., poz. 28).

Komunikat nr 16 Ministra Finansów z 18 lipca 2006 r. w sprawie ogłoszenia „Kodeksu etyki audytora wewnętrznego w jednostkach sektora finansów publicznych” i „Karty audytu wewnętrznego w jednostkach sektora finansów publicznych" (Dz. Urz. Min. Fin., nr 9, poz. 70).

Międzynarodowe Standardy Profesjonalnej Praktyki Audytu Wewnętrznego (2001). The Institute of Internal Auditors, USA. Tłum. IIA - Polska, Warszawa 2006. Pobrane z: www.iia.org.pl (16.08.2006). 
Nadolna, B. (2016). Balanced scorecard jako narzędzie oceny dokonań audytu wewnętrznego w jednostkach sektora finansów publicznych. Finanse, Rynki Finansowe, Ubezpieczenia, 6 (84/1), 333-346. DOI: 10.18276/ frfu.2016.84/1-29.

Rozporządzenie Ministra Finansów z dnia 4 września 2015 r. w sprawie audytu wewnętrznego oraz informacji o pracy i wynikach tego audytu (Dz.U. poz. 1480).

Szczepankiewicz, E.I., Młodzik, E. (2016). Doskonalenie jakości audytu wewnętrznego w jednostkach sektora finansów publicznych. Finanse, Rynki Finansowe, Ubezpieczenia, 6 (84/1), 139-150. DOI: 10.18276/ fru.2016.84/1-12.

Ustawa z dnia 27 sierpnia 2009 r. o finansach publicznych (t.j. Dz.U. 2016, poz. 1870 z późn. zm.).

Wytyczne do samooceny audytu wewnętrznego w jednostce sektora finansów publicznych (2003). Warszawa: Ministerstwo Finansów. Pobrane z: www.mf.gov.pl (12.12.2004).

Wytyczne do samooceny audytu wewnętrznego w jednostkach sektora finansów publicznych (2007). Warszawa: Departament Audytu Sektora Finansów Publicznych. Pobrane z: http://www.mf.gov.pl/c/document_library/get_file?uuid =17d5d2e3-4bbd-4afa-8be2-14b4196bf4ca\&groupId=764034 (1.05.2017).

Wytyczne w zakresie programu zapewnienia i poprawy jakości (2012). Warszawa: Departament Audytu Sektora Finansów Publicznych. Pobrane z: http://www.mf.gov.pl/c/document_library/get_file?uuid=cde04f02-547c4018-a954-dbc653951 f02\&groupId=764034 (1.05.2017).

Zaleska, B. (2015). Ocena funkcjonowania zleconego audytu wewnętrznego w wybranych jednostkach samorządu terytorialnego województwa zachodniopomorskiego. Zeszyty Naukowe Uniwersytetu Szczecińskiego. Finanse, Rynki Finansowe, Ubezpieczenia, 2 (76), 89-98.

\section{INTERNAL AUDIT VS. QUALITY VALUE ADDED IN PUBLIC FINANCE SECTOR UNITS}

Abstract: Purpose - Presentation of the added value brought by internal audits to the entity, as well as the impact of implementing an internal quality assessment and improvement program on adding value to the internal audit unit and the entity as a whole

Design/methodology/approach - Preparing the paper involved a review of literature, current law and regulations, and a critical analysis of internal documents and surveys carried out in the studied public finance sector units.

Findings - Results of questionnaire surveys on internal audit quality in selected entities of the public finance sector and entities operating in other sectors are presented.

Originality/value - The presented research results may serve as a hypothetical for theoreticians for further advanced research into the measurement and improvement of the quality of internal audit in various entities.

Keywords: internal audit, add value, valuation

\section{Cytowanie}

Szczepankiewicz, E.I. (2017). Jakość audytu wewnętrznego a wartość dodana w jednostkach sektora finansów publicznych. Finanse, Rynki Finansowe, Ubezpieczenia, 3 (87/1), s. 111-120. DOI: 10.18276/frfu.2017.87/1-10. 